\title{
IS Demodex REALLY NON-PATHOGENIC?
}

\author{
Gil Patrus PENA(1 ) \& José de Souza ANDRADE FILHO(2)
}

\begin{abstract}
SUMMARY
Although usually considered a non-pathogenic parasite in parasitological textbooks, Demodex folliculorum has been implicated as a causative agent for some dermatological conditions, such as rosacea-like eruptions and some types of blepharitis. Several anecdotal reports have demonstrated unequivocal tissue damage directly related to the presence of the parasite. However, this seems to be exceedingly rare, in contrast with the marked prevalence of this infestation. We have had the opportunity to observe one of such cases. A 38-year-old woman presented with rosacea-like papular lesions in her right cheek. Histopathological examination revealed granulomatous dermal inflammation with a well-preserved mite phagocytized by a multinucleated giant cell. This finding may be taken as an evidence for the pathogenicity of the parasite, inasmuch as it does not explain how such a common parasite is able to produce such a rare disease.
\end{abstract}

KEYWORDS: Demodex; Skin diseases; Host-parasite relationship

\section{INTRODUCTION}

One of the most difficult tasks in infectious diseases is to define pathogenic roles of microorganisms, that means, to determine causative agents of disease. More than a hundred years ago, Koch defined his postulates, and although taken as a paradigm on the subject, many pathogens are recognized without accomplishing them. Evidences in support of a causative role may be derived from epidemiological studies, as well as from molecular techniques ${ }^{6}$. These alternatives, however, are clearly limited in two circumstances: very rare diseases from one side, and very common (prevalent) causative agents in the other.

The demonstration of the pathogenicity of Demodex species is a difficult task. It has been said that with adequate sampling techniques, mites could be discovered in some follicles of the entire adult population ${ }^{3}$. On the other hand, lesions attributed to Demodex are extremely rare. In this report, we describe a case of Demodex attributed rosacea-like lesion. This report illustrates how it may be difficult to assign a "pathogenic" or "non-pathogenic" label to some parasites, disclosing the uncertainty that permeates biological sciences.

\section{CASE REPORT}

A 38-year old woman presented with erythemato-macular pruriginous lesions in the right cheek, which were clustered in a somewhat semicircular fashion. A punch biopsy was performed. The histopathological picture was that of a granulomatous dermal inflammation composed of epithelioid granulomas with giant cells and lymphocyte infiltrate (Fig. 1). Most interesting, a well-preserved Demodex mite was seen phagocytized by a multinucleated giant cell, in the vicinity of a hair follicle (Fig. 2). Demodex mites were also observed within undamaged hair follicles (Fig. 3).

A diagnosis of rosacea associated with intradermal Demodex was made.

\section{COMMENT}

Our case tentatively illustrates the pathogenic potential of Demodex. The participation of Demodex in the pathogenesis of skin lesions has long been a matter of debate. Many authors have reported Rosacea-like eruptions with aetiology attributed to Demodex $x^{1,2,4,7,8,9,10,12,13}$. Some of these papers deal with the density of the mite population, assuming that increased density is related to appearance of dermatological disturbances ${ }^{2,8,13}$. A few reports describe the presence of the parasite in the dermis, giving rise to the inflammatory reaction ${ }^{4,7,9}$. Other papers report isolated cases, attributing a pathogenic role to the apparent increase in the mite population ${ }^{10,12}$. There is also a report of a pustular dermatitis attributed to an intra-follicular Demodex ${ }^{1}$, what in our opinion is not sufficient to establish a causal link. Other authors deny any pathogenic role of Demodex ${ }^{5,11}$.

The causative connection between the infectious agent and the physiological disturbance will many times rest upon proposed

Work done in the "Setor de Anatomia Patológica do Laboratório Distrital Centro-Sul, Prefeitura de Belo Horizonte", MG, Brasil

(1) Pathologist - "Laboratório Distrital Centro-Sul, Prefeitura de Belo Horizonte", Minas Gerais, Brasil

(2) Full Professor of Pathology, Faculdade de Ciências Médicas de Minas Gerais, Belo Horizonte, MG, Brasil.

Correspondence to: Gil Patrus Pena. Rua Uberaba 418/102, 30180-080 Belo Horizonte, MG, Brasil. Fax 55 31 295-2688. e-mail: gilpena@gold.com.br 


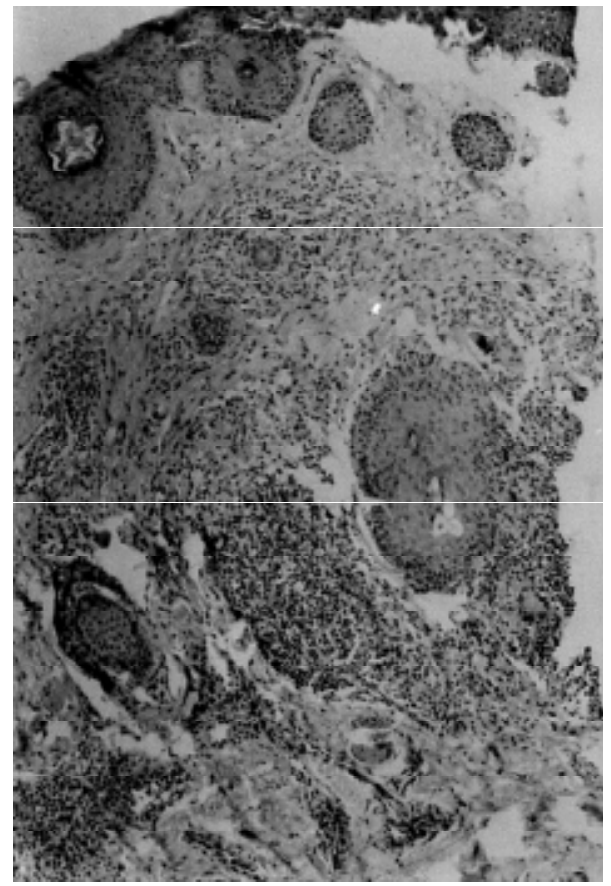

Fig. 1 - Low power view of the skin biopsy, showing multifocal dermal infiltrate, somewhat centered around skin adnexa, composed of mononuclear cells and some giant cells. The Demodex-containing giant cell can be seen in the direction of two o'clock, slightly superior and laterally to a hair follicle.

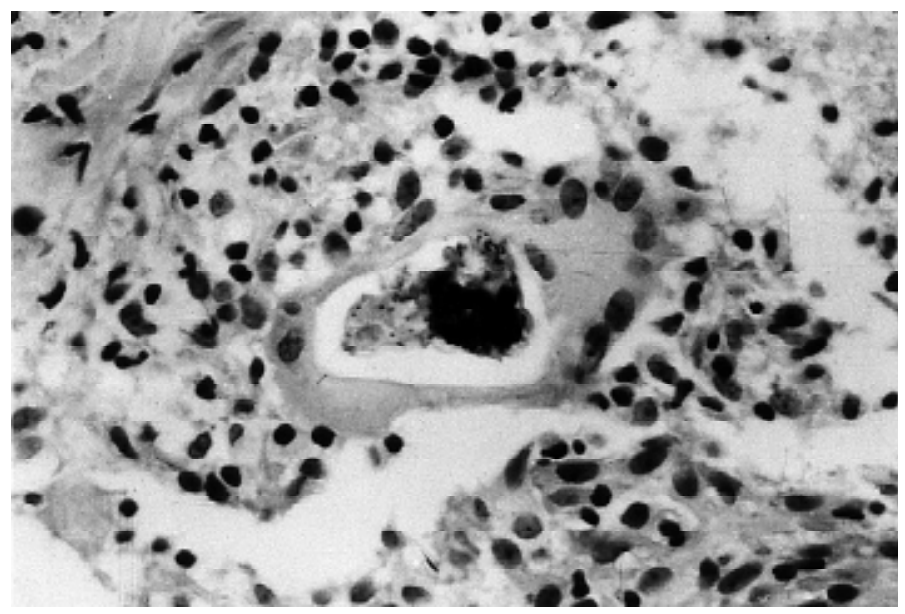

Fig. 2 - In a high power view, the Demodex mite is seen phagocytized by a multinucleated giant cell. Dermal infiltrate is composed mainly of lymphocytes and macrophages.

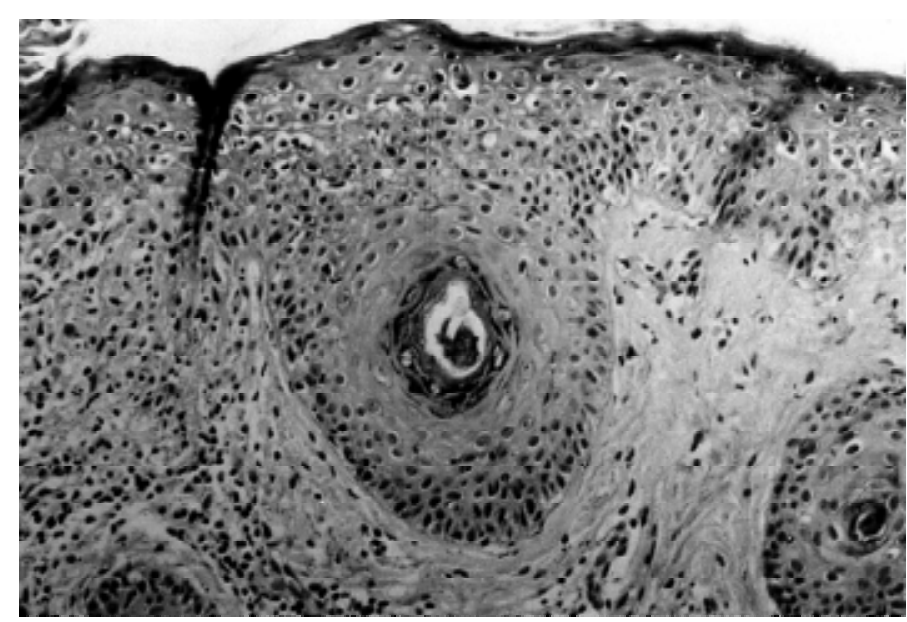

Fig. 3 - "Eutopic" Demodex mites were also observed, located within hair follicles.

pathogenetic mechanisms for the action of the parasite on the host, as well as the reactions by host tissues in the presence of the parasite. Proposed mechanisms for the presence of the mite within dermis must include active penetration or passive convey through a damaged pilosebaceous follicle. The former proposition does not seem feasible, although one report claims to have documented a mite penetrating an intact follicle wall ${ }^{7}$. We can surmise that the latter is true, from the rarity of those findings and the frequent association with rosacea-like dermal infiltrate around follicles without evidences of infestation. However, a definite clue to the pathogenicity of Demodex may not be achieved, by virtue of its prevalence among almost entire population and the rarity of manifestations attributed to it. Our report may be taken as evidence of a tissue damage associated with a Demodex mite. Although assuming that its presence within dermis may take place only through a previously damaged follicle, the giant cell reaction elicited was directly related to the parasite, which may be considered, at least, a secondary complicating factor in the pathogenesis of the lesion.

\section{RESUMO}

\section{O Demodex é realmente não patogênico?}

Embora geralmente considerado um parasita não patogênico nos livros-texto de parasitologia, Demodex folliculorum tem sido implicado como agente causal de algumas condições dermatológicas, como erupções tipo rosácea e alguns tipos de blefarite. Vários relatos isolados têm demonstrado alterações teciduais sem dúvida relacionadas diretamente à presença do parasita. Entretanto, esses achados são extremamente raros, ao contrário da enorme prevalência da infestação. Tivemos a oportunidade de observar um destes casos. Paciente do sexo feminino, com 38 anos, apresentou lesões papulosas rosaceiformes, na região zigomática direita. $\mathrm{O}$ exame histopatológico revelou inflamação dérmica granulomatosa, com um ácaro bem preservado, fagocitado por uma célula gigante. Esse achado pode ser considerado como evidência a favor da patogenicidade do parasita, embora não explique como um parasita tão comum pode ser capaz de produzir alteração tão rara. 


\section{REFERENCES}

1. AMICHAI, B.; GRUNWALD, M.H.; AVINOACH, I. \& HALEVY, S. - Granulomatous rosacea associated with Demodex folliculorum. Int. J. Derm., 31: 718-719, 1992.

2. BONNAR, E.; EUSTACE, P. \& POWELL, F.C. - The Demodex mite population in rosacea. J. Amer. Acad. Derm., 28: 443-448, 1993.

3. BURNS, D.A. - Diseases caused by arthropods and other noxious animals. In: CHAMPION, R.H.; BURTON, J.L. \& EBLING, F.J.G. Rook/Wilkson/Ebling Textbook of Dermatology. 5. ed. Oxford, Blackwell, 1994. v. 2, p. 1315-1317.

4. ECKER, R.I. \& WINKELMANN, R.K. - Demodex granuloma. Arch. Derm., 115: 343 344, 1979.

5. ERLACH, E.; GEBHART, W. \& NIEBAUER, G. - Zur Pathogenese der granulomatösen Rosacea. Z. Hautkr., 51: 459-464, 1976.

6. FALKOW, S. - Molecular Koch's postulates applied to microbial pathogenicity. Rev. infect. Dis., 10: S274-S279, 1988.
7. FORTON, F. - Démodex et inflammation périfolliculaire chez l'homme: revue et observation de 69 biopsies. Ann. Derm. Vénéreol., 113: 1047-1058, 1986.

8. FORTON, F. \& SEYS, B. - Density of Demodex folliculorum in rosacea: a case control study using standardized skin-surface biopsy. Brit. J. Derm., 128: 650-659, 1993.

9. GROSSHANS, E.; KREMER, M. \& MALEVILLE, J. - Demodex folliculorum und die Histogenese der granulomatösen Rosacea. Hautarzt, 25: 166-177, 1974.

10. MATEO, J.R.; GUZMÁN, O.S.; RUBIO, E.F. \& FRANJO, F.D. - Demodex-attributed rosacea-like lesions in AIDS. Acta derm. venereol. (Stockh.), 73: 437, 1993.

11. RAMELET, A.-A. \& PERROULAZ, G. - Rosacée: étude histopathologique de 75 cas. Ann. Derm. Vénéreol., 115: 801-806, 1988.

12. SHELLEY, W.B.; SHELLEY, E.D. \& BURMEISTER, V. - Unilateral demodectic rosacea. J. Amer. Acad. Derm., 20: 915-917, 1989.

13. SIBENGE, S. \& GAWKRODGER, D.J. - Rosacea: a study of clinical patterns, blood flow, and the role of Demodex folliculorum. J.Amer.Acad. Derm., 26: 590-593, 1992.

Received: 10 January 2000

Accepted: 16 February 2000 